p-ISSN: 2337-5280, e-ISSN: 2620-7427

\title{
IMPLEMENTASI DAN EFEKTIFITAS PENGGUNAAN MOBILE LEARNING TERHADAP HASIL BELAJAR MAHASISWA PROGRAM STUDI SISTEM INFORMASI STIKOM UYELINDO KUPANG
}

\author{
Sumarlin $^{1}$, Edwin A. U. Malahina ${ }^{2}$ \\ Program Studi Sistem Informasi ${ }^{1}$, Program Studi Teknik Informatika ${ }^{2}$ \\ STIKOM Uyelindo Kupang \\ E-mail :shumarlin@gmail.com,edwinariesto@gmail.com
}

\begin{abstract}
This research was made aiming to implement and improve the effectiveness of learning media through mobile-based mobile learning for all courses in Uyelindo Kupang STIKOM information system students. The research target to be achieved is an additional learning media that is interesting and easy to use so that it can increase student interest and student achievement. This research will discuss how to design, develop and evaluate the effectiveness of using Mobile Learning applications. This application is made so that students can easily access a course material using the Mobile Learning application by Smartphone and also to increase the effectiveness of conducting online lectures at the Uyelindo Kupang STIKOM information system study program. To measure the effectiveness of the use of mobile learning it is necessary to test among them, from the results of the Kolmogorov-Smirnov test using SPSS 16 it is found that the research subjects are normally distributed and based on the results of the Paired Samples Test t-test it is known that the significant value is 0,000>0,05. While t-count = 11,142 and for t-table at a significant level $\alpha=5 \%(0.05)$ with degrees of freedom (df) $n-1$ or $50-1=$ 49. Two-sided testing (significance $=0.025$ ) results are obtained for t-table $=2,00958$ with a significant level of 0.025 . In the result t-count $<t$-table $(-11.142<2$, 00958) then $\mathrm{HO}$ is rejected and Ha is accepted. So that the use of mobile learning media can improve student learning outcomes at the Uyelindo Kupang STIKOM information system.
\end{abstract}

Keywords : Mobile Learning, Kolmogorov-Smirnov, Paired Samples Test t-test

\section{PENDAHULUAN}

\subsection{Latar Belakang}

Pada saat ini perkembangan teknologi sudah semakin maju, yang mana melalui mobile seseorang bisa mendapatkan informasi yang berguna dengan mudah. Oleh karena itu teknologi mobile dapat dimanfaatkan oleh dunia pendidikan sebagai sarana informasi bagi masyarakat. Pemanfaatan mobile juga sudah dapat dirasakan didalam proses pembelajaran. Pemanfaatan teknologi informasi sebagai media pembelajaran dalam dunia pendidikan sudah mulai digunakan di kampus-kampus, termasuk di STIKOM Uyelindo Kupang. Sebagaimana seorang pengajar di suatu kampus, Teknologi mobile dapat digunakan sebagai media dalam proses belajar mengajar yang mempunyai fungsi sebagai media tutorial, alat peraga dan alat uji sehingga akan sangat membantu dalam proses penyampaian dan pemahaman terhadap materi kepada mahasiswa dimana saja dan kapan saja

Pendemi Covid-19 yang terjadi sejak awal tahun 2020 ini mengakibatkan terjadinya perubahan kebijakan secara mendasar dalam dunia pendidikan tanah air. Menteri Pendidikan dan Kebudayaan RI, telah mengeluarkan beberapa kebijakan untuk mengatur kegiatan pembelaran selama masa pandemi ini. Hal tersebut dikeluarkan melalui Surat edaran Nomor 4 Tahun 2020 [10], yaitu tentang Pelaksanaan Kebijakan Pendidikan dalam Masa Darurat Penyebaran Coronavirus Disease (Covid-19), tertanggal 24 Maret 2020. tepatnya ada 6 (enam) kebijakan yang dipaparkan dengan jelas. Namun, yang paling mendasar ialah merubah cara belajar mengajar siswa dan guru adalah kebijakan belajar dari rumah, salah satu pembelajaran daring yang efektif yaitu mobile learning. 
Mobile learning merupakan salah satu alternatif yang sangat potensial untuk dikembangkan saat ini. Hal ini didasarkan pada fakta yang ada bahwa jumlah penggunaan perangkat mobile untuk aktivitas di Internet semakin meningkat. Menurut laporan terakhir yang disampaikan oleh Nielsen, sekitar $78 \%$ pengguna Internet di Indonesia mengakses Internet menggunakan mobile phone (handphone), 29\% menggunakan laptop, $31 \%$ menggunakan desktop computer, dan $2 \%$ menggunakan tablet. Data tersebut menunjukkan bahwa jumlah pengguna Internet yang mengakses via perangkat mobile melebihi jumlah pengguna yang mengakses dengan menggunakan desktop computer. Masih menggunakan data yang disampaikan oleh Nielsen, rata -rata orang Indonesia menghabiskan waktu lebih dari empat belas jam per minggu untuk dalam menggunakan internet [8].

M-Learning dianggap sebagai suplemen untuk E-Learning tradisional dimana mobilitas adalah nilai tambah bagi para peserta didik. Data kursus atau perkuliahan dapat dimanfaatkan sehingga tidak perlu membuat sistem M-Learningterpisah dari E-Learning[5]. E-learning adalah sebuah proses pembelajaran yang berbasis elektronik [6]. Yang memungkinkan untuk diimplementasikan pada smartphone Android menjadi M-Learning.

Dengan menggunakan metode $m$ learning, dosen memiliki kemampuan untuk meningkatkan intensitas komunikasi interaktif dengan mahasiswa di luar jadwal kuliah resmi. Metode m-learning memberikan keleluasaan pada dosen untuk memberikan akses kepada mahasiswa untuk mendapatkan referensi ilmiah terkait dengan mata kuliah tersebut yang mungkin tidak didapat pada saat kuliah maupun praktikum. Seluruh referensi berupa tulisan ilmiah, artikel populer atau jurnaljurnal elektronik dapatdiberikan melalui $e$ learning. Hal ini sangat berguna bagi mahasiswa, karena selain dapat memperkuat pemahaman mahasiswa untuk tiap pokok bahasan perkuliahan, referensi dari jurnaljurnal internasional akan sangat membantu dalam memperluas wawasan mahasiswa sekaligus kemampuan mahasiswa [3].

Adapun hasil analisis kebutuhan yang telah dilakukan peneliti di STIKOM Uyelindo Kupang program studi siste informasi pada mahasiswa angkatan 2016 - 2018 dengan jumlah sampel 50 mahasiswa melalui observasi, hasilnya 100\% mahasiswa memiliki smartphone. Selain itu, $98 \%$ mahasiswa dapat menggunakan smartphone dengan baik. Berdasarkan hasil analisis pengamatan kepada Dosen menunjukkan bahwa rerata hanya menggunakan sarana media LCD proyektor dan merangkum materi ke slide powerpoint. Ada juga yang hanya menggunakan modul berbasis cetak.

Berdasarkan hasil pengamatan kebutuhan mahasiswa diketahui $60 \%$ lebih mahasiswa masih kurang memahami penyampaian materi menggunakan media LCD proyektor. Mahasiswa cenderung merasa bosan dengan pembelajaran yang diterapkan Dosen yang hanya menggunakan metode ceramah dan diskusi. Oleh karena itu, untuk meningkatkan gairah belajar dan pemahaman mahasiswa terhadap mata kuliah pada prodi sistem informasi, maka mengembangkan media mobile learning yang menarik dan responsive.

\subsection{Perumusan Masalah}

Berdasarkan uraian latar belakang, masalah yang ditemukan adalah bagaimana mengembangkan dan menerapkan aplikasi mlearning agar dapat digunakan secara maksimal oleh dosen dan mahasiswa program studi Sistem Informasi STIKOM Uyelindo Kupang?. Aplikasi Mobile Learning harus dirancang secara lebih efektif, efisien dan optimal dibandingkan dengan aplikasi yang dirancang untuk E-learning.

\subsection{Tujuan Penelitian}

Adapun yang menjadi tujuan dalam penelitian ini adalah membangun media pembelajaran m-learning yang menarik agar secara maksimal dapat digunakan oleh dosen dan mahasiswa prgram studi Sistem Informasi STIKOM Uyelindo Kupang dan dapat digunakan sebagai media belajar pelengkap mahasiswa di kampus.

Dengan adanya aplikasi ini diharapkan dapat menarik minat mahasiswa untuk belajar dan dapat meningkatkan prestasi belajar mahasiswa pada semua mata kuliah di prodi Sistem Informasi. Dengan adanya aplikasi ini juga diharapkan dapat memberi manfaat dan pengetahuan bagi mahasiswa tentang pembelajaran semua mata kuliah pada prodi Sistem Informasi yang lebih dalam dan jelas. 


\section{TINJAUAN PUSTAKA}

\subsection{Mobile Learning}

Mobil learning atau disingkat dengan $\mathrm{m}$ learning merupakan suatu teknologi pembelajaran dengan menggunakan perangkat mobile yang memungkinkan seseorang (siswa) untuk mengakses informasi dan materi pembelajaran kapan pun dan dimana pun [1]. Dengan menggunakan mobile learning, siswa mempunyai kebebasan untuk menentukan kapan dan dimana proses pembelajaran akan dilaksanakan. Mobile learning juga memberikan kebebasan untuk mengakses informasi serta materi pembelajaran yang dapat meningkatkan kualitas kehidupan seseorang tanpa memperhatikan tempat tinggal, status sosial, maupun kebudayaan seseorang.

Mobile learning mempunyai kaitan yang cukup erat dengan e-learning. Pada dasarnya, mobile learning merupakan pengembangan dari konsep e-learning. E-learning sendiri merupakan bagian dari pembelajaran jarak jauh (distance learning) sehingga, mobile learning juga merupakan bagian dari distance learning [4].

Perangkat mobile seperti laptop, dan telepon seluler telah menjadi alat pembelajaran dengan potensi besar dalam pembelajaran di kelas dan di luar ruangan. Meskipun ada analisis kualitatif tentang penggunaan perangkat seluler dalam pendidikan, analisis kuantitatif sistematis tentang dampak pendidikan terpadu seluler masih kurang [11].

\subsection{Kerangka Mobile Learning}

Setiap pengembangan sistem mobile learning selalu terdiri dari tiga domain utama yaitu mobile usability, wireless technology, elearning system [7]. Hubungan dari ketiga ranah tersebut dapat dilihat pada gambar 1.

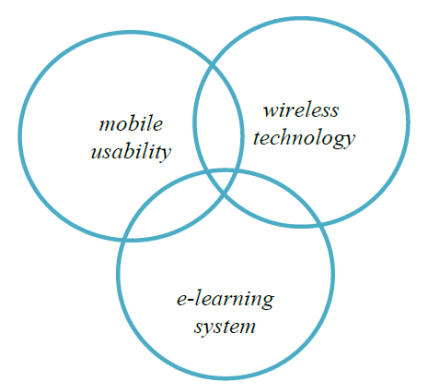

Gambar 1. Ranah Sistem Mobile Learning

Mobile Usability atau penggunaan perangkat mobile merupakan bagian yang penting dalam sebuah sistem mobile learning.

Perangkat mobile difungsikan untuk mengelola dan menampilkan media pembelajaran. Perangkat mobile tidak hanya terbatas pada mobile phone (handphone) semata, namun bisa juga mencakup tablet pc, palmtop, atau perangkat pemutar musik seperti iPod.

Ranah selanjutnya yaitu wireless technology atau teknologi nirkabel. Sebuah perangkat tidak bisa dikatakan perangkat mobile jika masih harus terhubung ke jaringan melalui sebuah kabel. Oleh karena itu, teknologi nirkabel erat kaitannya dengan perangkat mobile. Teknologi nirkabel dalam sistem mobile learning berfungsi sebagai sarana untuk saling berkirim data. Teknologi tersebut tidak hanya terbatas pada jaringan operator semata, namun mencakup pada teknologi bluetooth, inframerah, Wi-Fi, maupun teknologi nirkabel lainnya.

Sistem e-learning menjadi pusat utama sumber pembelajaran. Perangkat mobile difungsikan untuk menampilkan media pembelajaran, teknologi wireless difungsikan untuk mengirim dan menerima data, sedangkan sistem e-learning bertugas untuk mengelola sumber pembelajaran.

Seiring dengan perkembangan jaman, teknik dan metode pembelajaran pun telah bergeser dari pola tradisional yang bersifat techer center ke pembelajaran berbasis teknologi yang menempatkan siswa sebagai pembelajaran utama (student center). Era pembelajaran mobile yang berbasis pada penggunaan internet sebagai sarana belajar telah memberikan peran yang lebih besar pada guru sebagai fasilitator dan motivator pembelajaran [13]. Penerapan mobile learning merupakan bentuk pembelajaran modern, dimana teknologi informasi dan komunikasi sangat berperan penting dalam membentuk konsep pembelajaran modern [14].

\section{METODE}

Menurut Sugiyon metode penelitian diartikan sebagai cara ilmiah untuk mendapatkan data dengan tujuan dan kegunaan tertentu [9]. Dengan metode penelitian, penulis mengumpulkan data historis dan mengamati secara seksama mengenai aspek-aspek tertentu yang berkaitan erat dengan masalah yang diteliti sehingga diperoleh data-data yang menunjang penelitian [12]. Penelitian ini dilakukan pada prodi 
Sistem Informasi STIKOM Uyelindo Kupang sejak bulan agustus tahun 2019. Sampel penelitian yang digunakan diambil dari beberapa mahasiswa prodi sistem informasi dengan total sampel sebanyak 50 responden. Data penelitian yang diperoleh berupa data standarisasi media pembelajaran menggunakan data hasil belajar.

\subsection{Jenis Penelitian}

Jenis penelitian yang digunakan dalam pengembangan aplikasi mobile learning ini termasuk jenis penelitian pengembangan (Research and Development). Menurut Borg and Gall yang dimaksud dengan Research dan Development (R\&D) adalah proses mengembangkan dan menvalidasi produk pendidikan (a process used develop and validate educational product) [2]. Tujuan utama dari metode penelitian ini bukanlah untuk menghasilkan teori baru maupun menguji teori yang sudah ada, melainkan untuk menghasilkan sebuah produk baru atau mengembangkan produk yang sudah ada yang berguna untuk pembelajaran di sekolah. Produk yang akan dihasilkan dalam penelitian ini adalah aplikasi mobile learning yang dapat digunakan untuk membantu persiapan ujian bagi siswa sekolah menengah atas.

\subsection{Desain Arsitektur Fisik Sistem}

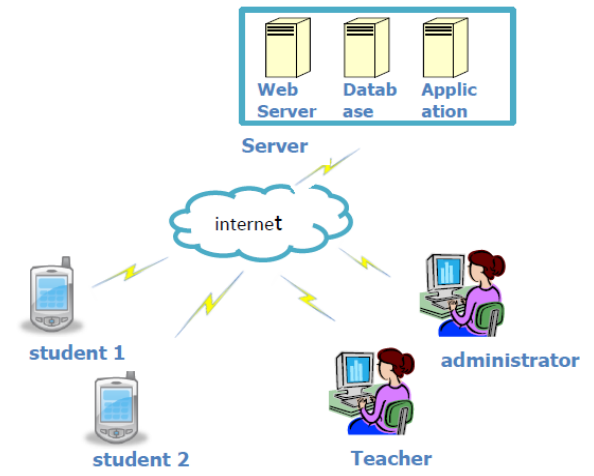

Gambar 2. Arsitektur Fisik Sistem

Pada gambar 2 menunjukkan bahwa aplikasi yang dibuat terdiri dari dua komponen utama, yaitu application client, dan server. Application client merupakan front-end aplikasi yang digunakan oleh user. Application client terdiri dari dua device yang berbeda. Mobile device merupakan device yang digunakan oleh mahasiswa dan merupakan tempat aplikasi terinstall. Sedangkan user yang bertindak sebagai dosen dan administrator akan menggunakan perangkat komputer (desktop pc atau laptop) yang mempunyai layar serta resolusi yang lebih besar dari pada perangkat mobile.

\subsection{Desain Model \\ 1. Use Case Diagram}

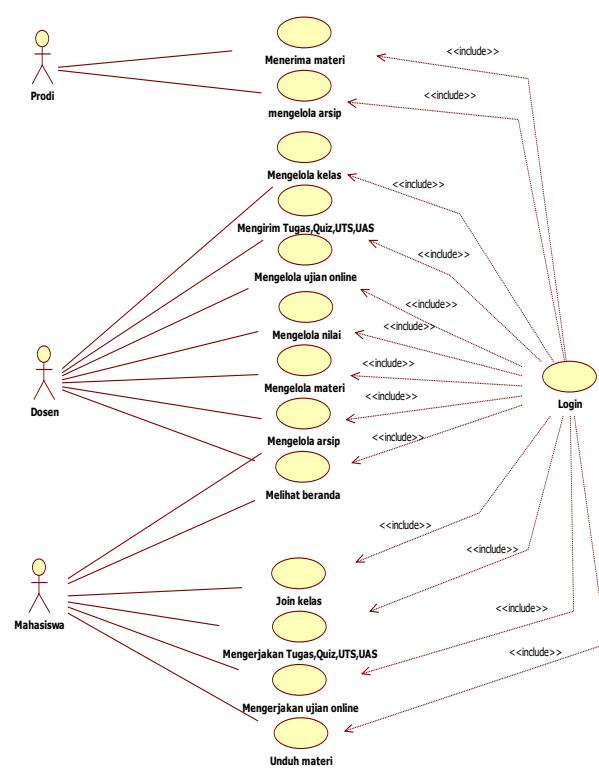

Gambar 3. Usecase Diagram

Use case diagram mendefinisikan fitur fitur yang terdapat di dalam sistem. Fitur fitur tersebut merupakan hasil dari analisis kebutuhan pengguna (function requirement). Use case diagram juga merepresentasikan interaksi antara aktor dengan use case lainnya. Aktor adalah sebuah entitas manusia atau mesin yang berinteraksi dengan sistem yang bertujuan untuk melakukan suatu pekerjaan. Sedangkan use case merupakan sebuah pekerjaan tertentu yang dapat dilakukan oleh aktor.

\section{Class Diagram}

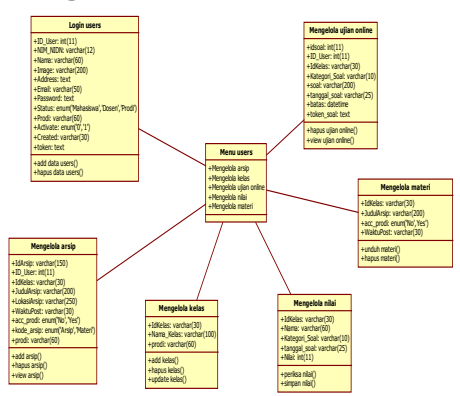

Gambar 4. Class Diagram

Class diagram merupakan suatu
diagram yang memperlihatkan atau


menampilkan struktur dari sebuah sistem, sistem tersebut akan menampilkan sistem kelas, atribut, dan hubungan antara kelas ketika suatu sistem telah selesai membuat diagram. Gambar class diagram dapat dilihat pada gambar berikut ini.

\section{HASIL DAN PEMBAHASAN \\ 4.1 Tampilan Halaman Sistem}

Untuk mengimplementasikan sistem ini maka dibuatlah sebuah menu secara interaktif untuk mempermudah pengguna dalam melakukan manipulasi data melalui inteface yang ada.

1. Tampilan halaman website

Halaman utama merupakan halaman yang akan tampil pertama disaat website akan ditampilkan.

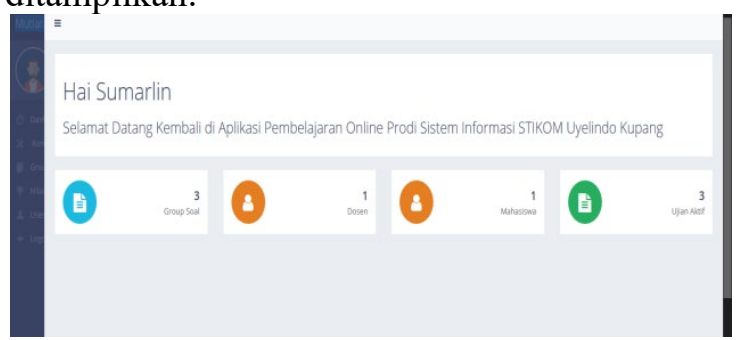

Gambar 5. Halaman Awal Website

2. Tampilan halaman Ujian online

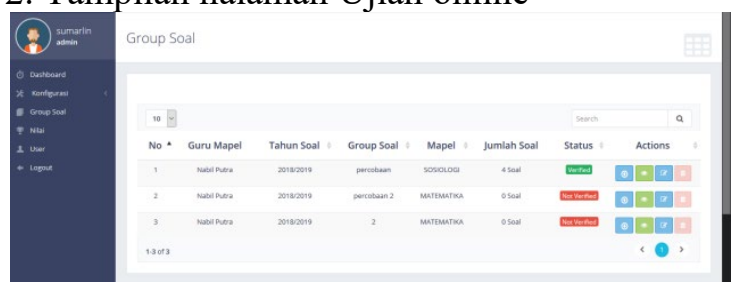

Gambar 6. Halaman Ujian Online

Halaman ini digunakan oleh dosen dan mahasiswa dalam berinteraksi pelaksanaan ujian tengah semester (UTS) maupun ujian akhir semester (UAS) secara online.

\section{Halaman Input data ujian}

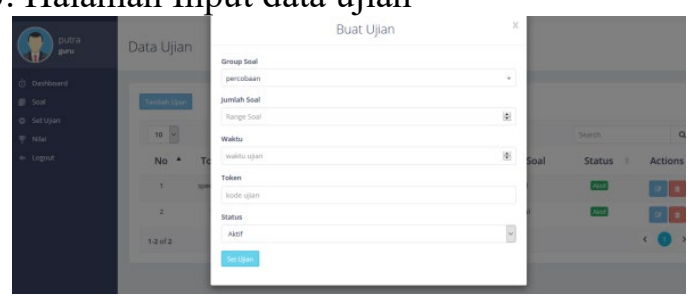

Gambar 7. Halaman data ujian

Halaman ini digunakan oleh dosen untuk menginput data soal ujian online.

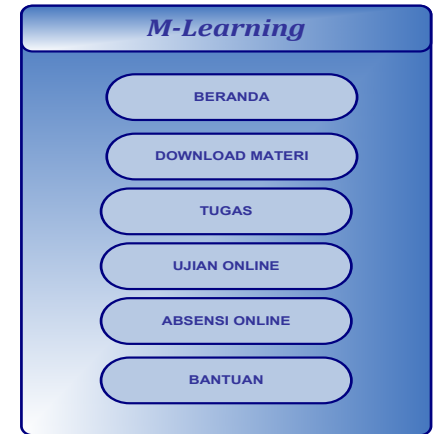

Gambar 8. Tampilan Halaman Mobile

Halaman ini digunakan oleh mahasiswa untuk berinteraksi dengan sistem, semua informasi yang berkaitan dengan perkuliahan online dapat dilihat pada tampilan halaman mobile.

\subsection{Pengujian Sistem}

Tahapan akhir dimana sistem yang baru diuji kemampuan dan keefektifannya sehingga kekurangan dan kelemahan sistem yang kemudian akan dilakukan pengkajian ulang dan perbaikan terhadap aplikasi menjadi lebih baik dan sempurna. Pengujian dilakukan dengan menguji fungsionalitas sistem dan pengujian pengguna.

\section{Pengujian Efektifitas Penerapan Mobile Learning}

Efektifitas penggunaan media mobile learning terhadap hasil belajar mahasiswa di prodi Sistem Informasi STIKOM Uyelindo Kupang, dapat diketahui dengan mengetahui perbandingan hasil belajar sebelum penerapan pre-test. Dengan penerapan post-test, media mobile learning.

Tabel 1. Descriptive Statistics Descriptive Statistics

\begin{tabular}{|l|r|r|r|c|r|}
\hline & \multicolumn{1}{|c|}{ N } & Minimum & Maximum & Mean & Std. Deviation \\
\hline PRE_TEST & 50 & 56.00 & 85.00 & 73.1200 & 7.70274 \\
POST_TEST & 50 & 70.00 & 96.00 & 83.0800 & 6.03676 \\
Valid N (listwise) & 50 & & & & \\
\hline
\end{tabular}

Berdasarkan tabel 1, diketahui hasil ratarata pre-test dan post-test mahasiswa yang berbeda. Hasil perolehan nilai rerata pre-test mahasiswa adalah 73,12 sedangkan hasil posttest mahasiswa adalah 83,08. Hal ini menunjukkan nilai post-test lebih baik dari pada nilai pre-test yaitu $83,08>73,12$. Secara umum mahasiswa mengalami peningkatan hasil belajar rata-rata sebesar 10. Sehingga ada perbedaan nilai rerata hasil penggunaan 
produk pengembangan media mobile learning yang dilakukan peneliti. Untuk lebih memperkuat hasil analisa, maka dilakukan analisis uji-t yaitu paired sample test dengan membuat hipotesis:

Ha: Terdapat perbedaan yang signifikan pada hasil belajar mahasiswa sebelum dan sesudah menggunakan media mobile learning.

H0: Tidak terdapat perbedaan yang signifikan pada hasil belajar mahasiswa sebelum dan sesudah menggunakan media mobile learning.

Selanjutnya melakukan uji perbedaan dua rata-rata dengan uji-t. Namun sebelumnya, terlebih dahulu dilakukan uji normalitas data dari nilai pre-test dan nilai post-test. Normalitas data nilai hasil tes dalam penelitian merupakan persyaratan yang harus dipenuhi untuk melakukan analisis inferensial, dengan menggunakan teknik statistik parametrik. Hasil uji terhadap hasil belajar mahasiswa nilai pre-test maupun post-test dilakukan dengan menggunakan program SPSS 16.

Tabel 2. Hasil Perhitungan One-Sample Kolmogorov-Smirnov Test

\begin{tabular}{|c|c|c|c|}
\hline \multicolumn{4}{|c|}{ One-Sample Kolmogorov-Smirnov Test } \\
\hline & & POST_TEST & PRE_TEST \\
\hline N & & 50 & 50 \\
\hline Normal Parameters ${ }^{2}$ & Mean & 86.7800 & 73.1200 \\
\hline & Std. Deviation & 5.39194 & 7.70274 \\
\hline Most Extreme Differences & Absolute & .156 & .106 \\
\hline & Positive & .136 & .076 \\
\hline & Negative & -.156 & -.106 \\
\hline Kolmogorov-Smirnov Z & & 1.105 & .748 \\
\hline Asymp. Sig. (2-tailed) & & .174 & 631 \\
\hline
\end{tabular}

Hasil uji normalitas dengan menggunakan one sample kolmogorovsmirnov test terhadap nilai pre-test dan nilai post-test mahasiswa pada tabel 2 diperoleh nilai signifikan lebih besar dari 0,05 , yaitu pretest sebesar 0,631 dan post-test sebesar 0,174. Nilai tersebut lebih besar dari taraf nyata 0,05 yakni 0,631 dan $0,174>0,05$.

Hal tersebut berarti subjek penelitian berdistribusi normal dan syarat untuk melakukan analisis uji Paired Sample Test telah terpenuhi. Langkah selanjutnya adalah menganalisis data nilai pre-test dan post-test yang dilakukan dengan uji Paired Sample Test. Hal ini dilakukan untuk mengetahui apakah terjadi perbedaan yang signifikan antara nilai rata-rata mahasiswa sebelum dengan sesudah mengikuti pembelajaran dengan menggunakan media mobile learning. Uji-t (Paired Sample Test) dilakukan dengan menggunakan SPSS 16 dengan taraf kepercayaan $95 \%$ atau signifikansi 0,05 . Hasil uji Paired Sample Test seperti ditunjukkan pada tabel 3 .

Tabel 3. Hasil Uji Paired Samples Test

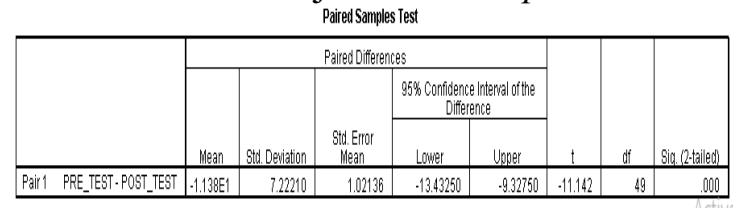

Berdasarkan hasil uji Paired Samples Test diketahui nilai thitung diperoleh sebesar 11.142, dan untuk t-tabel diperoleh dengan cara $\alpha=5 \% / 2=2,5 \%$ (untuk uji 2 sisi) dengan derajat kebebasan (df) n-1 atau 50-1 = 49. Pengujian 2 sisi (signifikansi $=0,025$ ) dengan hasil perolehan ttabel pada 2.00958 dengan taraf signifikan 0,025. Hasilnya menunjukkan -thitung < -ttabel $(-11.142<$ 2.00958). Thitung bernilai negatif, sehingga nilai rerata pre-test lebih rendah dari nilai rerata post-test.

Oleh karena nilai sig. (2-tailed) 0,000 lebih besar dari 0,05, dapat disimpulkan $\mathrm{H} 0$ ditolak dan $\mathrm{Ha}$ diterima. Sehingga uraian tersebut dapat diartikan terdapat perbedaan yang signifikan antara hasil belajar mahasiswa prodi sistem informasi STIKOM Uyelindo Kupang sebelum dan setelah penerapan media mobile. Sehingga secara efektif bisa meningkatkan hasil belajar mahasiswa.

\section{KESIMPULAN}

Adapun kesimpulan yang didapat dalam penulisan hasil penelitian ini adalah:

a. Berhasil dibuatnya sebuah aplikasi media learning sebagai media pembelajaran bagi mahasiswa di prodi Sistem Informasi STIKOM Uyelindo Kupang yang berbasis mobile learning yang menarik dan interaktif.

b. Aplikasi media learning ini dapat membantu mahasiswa dalam memahami pembelajaran di prodi Sistem Informasi.

c. Aplikasi media learning yang dikembangkan sangat efektif digunakan khususnya ditengah Pandemi Covid 19 yang terjadi saat ini yang mengharuskan 
kita belajar dari rumah (Study From Home).

d. Berdasarkan data pre-test dan post-test dari 50 mahasiswa program studi sistem informasi diperoleh hasil uji paired samples test diketahui nilai sig. (2tailed) 0,000 lebih besar dari 0,05, dan hasil thitung < ttabel yaitu $-11.142<$ 2.00958. Sehingga dapat dinyatakan bahwa terdapat perbedaan signifikan antara hasil belajar sebelum dan setelah penerapan media mobile learning. Untuk itu, media hasil pengembangan dengan efektif mampu meningkatkan hasil belajar mahasiswa prodi sistem informasi STIKOM Uyelindo Kupang.

\section{DAFTAR PUSTAKA}

[1] Ally, M. 2009. Mobile learning: transforming the delivery of education and training. Edmonton: AU Press.

[2] Borg, W.R., \& Gall, M.G. 1989. Education Research : An Introduction. 5rd.New York: Longman

[3] Budi, Bryan, N., 2012. Pengemabngan Metode Pembelajaran Online Berbasis E-Learning (Studi Kasus Mata Kuliah Bahasa Pemrograman), Jurnal Sains Terapan Edisi II Vol-2 (1) : 103 - 113.

[4] Georgiev, E. G., \& Smrikarov, A. 2004. M-Learning - a New Stage of ELearning, International Conference on Computer Systems and Technologies CompSysTech' 2004.

[5] Hidayat R., Satriyo A., Panji W.W., 2013. "Perancangan dan Pembuatan Mobile Learning Interaktif Berbasis Android dengan Metode Personal Extreme Programming", Universitas Diponegoro.

[6] Hidayati, Novi, 2010. "Sistem ELearning Untuk Meningkatkan Proses Belajar Mengajar: Studi Kasus Pada SMA Negeri 10 Bandar Lampung" Jurnal TELEMATIKAMKOM, Vol.2 No.2
[7] Mostakhdemin-hosseini, A., \& Mustajärvi, J. (2003). Framework for Mobile Learning System Based on Education Component. In Proceedings of the International Conference on Theory and Applications of Mathematics and Informatics (pp. 191196). Alba Iulia.

[8] Nielsen. 2010. Surging Internet Usage in Southeast Asia Reshaping The Media Landscape. Diakses dari http://blog.nielsen.com/nielsenwire/glob $\mathrm{al} /$ surging-internet-usage-in-southeastasia-reshaping-the-media-landscape

[9] Sugiyono. 2014. Metode Penelitian Pendidikan Pendekatan Kuantitatif, Kualitatif, dan R\&D. Bandung: Alfabeta

[10] Surat Edaran Mendikbud No 4 Tahun 2020 Tentang Pelaksanaan Kebijakan Pendidikan Dalam Masa Darurat Penyebaran Corona Virus Disease (Covid- 19).

[11] Sutama. 2016. Metode Penelitian Pendidikan Kuantitatif, Kualitatif, PTK, R\&D. Surakarta : Fairuz Media.

[12] Sung, Yao-Ting, dkk. 2016. "The effects of integrating mobile devices with teaching and learning on students' learning performance: A meta-analysis and research synthesis". Computers \& Education94 : 252-275

[13] Aripin, I., 2018. Konsep dan Aplikasi Mobile Learning Dalam Pembelajaran Biologi, Bio Education. Vol 3, No 1. 